Economics Development Analysis Journal 9 (2) (2020)

Economics Development Analysis Journal

http://journal.unnes.ac.id/sju/index.php/edaj

\title{
Human Capital and Productivity: a Case Study of East Java
}

\author{
Sugeng Setyadi $^{1 \bowtie}$, Rizal Syaifudin $^{2}$, Deris Desmawan $^{3}$ \\ Universitas Sultan Ageng Tirtayasa
}

\begin{tabular}{l}
\hline Article Information \\
\hline History of Article \\
Received January 2020 \\
Accepted March 2020 \\
Pusblished May 2020 \\
_____-_E: \\
Human Capital, \\
Productivity, Literacy \\
Rate, Infant Mortality \\
Rate \\
\hline
\end{tabular}

\begin{abstract}
This research examines the influence of level of education and health rate as the measurement of human capital to productivity in East Java Provice, during 2009 to 2015. Variable of level of education is measured by literacy rate, while the variable of health rate is measured by infant mortality rate. The panel data analysis is used as research method, which is Fixed Effect Model is the best model than the other models. The research results show that the variable of level of education is not significant to productivity, whreas, the variable healt rate has negative and significant influence to productivity. The reason is because educated worker is not really nedded in East Java Province. Some workers with skills and experiences are preferred. Therefore, in this research literacy rate cannot be used as good proxy to measured variable of level of education. Moreover, a decrease in infant mortality rate is indicating that the health rate is good. Hence, productivity will increase if the helath of labor increase.
\end{abstract}

(C) 2020, Universitas Negeri Semarang

\footnotetext{
${ }^{\square}$ Corresponding author:

Address: Universiatas Sultan Ageng Tirtayasa

E-mail:sugeng.setyadi@untirta.ac.id
} 


\section{INTRODUCTION}

The purpose of this research is to analyze the influence of human capital and productivity in East Java Province during 2009 to 2015. The location of East Java Province is on the eastern part of Java Island. East Java Province's economy growth having place in the second rank of the highest regional economic growth after Jakarta. According to the Central Berau of Satatistic data, in 2012 the economy growth in East Java Province achieved $6.64 \%$ or increase as many as $0.2 \%$ from $6.44 \%$ in 2011 . The Gross National Product (GDP) of East Java Povince has big contribution to an increase in National GDP. In 2012, East Java province contributed as many as $14.87 \%$ of national GDP, and it increased to $14.99 \%$ in 2013. During 2011 to 2013 East Java Province's Human Capital Index (HDI) has positive trend. On 201, HDI of this province was $66.06 \%$ and increased to $66.74 \%$ in 2012 , and to $67.55 \%$ in 2013 . Higher of HDI means that the quality of social-economy is good. Event though the performance of GDP and HDI in East Java Province is good, however the poverty and unemployment rate in this province is still high. The percentage of poor people living below the poverty in the rural area was $16.88 \%$ and in the urban area was $8.90 \%$ in 2012 . In 2013 , the poverty rate both in the rural area and urban area decrease as many as $16.23 \%$. The number of unemployment rate 2012 was $4.09 \%$ and increased to $4.30 \%$ in 2013. Moreover, in 2013 the percentage of job occupancy was domintaded by some people who worked in agricultural sector as many as $38.25 \%$ and some people who worked in trade sector as many as many as $20.78 \%$ of total workers. Then in 2013 , as many as $52.61 \%$ the number of job occupancy according to the education rate was dominated by some workers who gradutaed from elementary school.

To analyze economy performance of a country, economic growth is the one of important indicators. Basically, economy growth shows the ability of a country to generate outputs. Labor and capital are some factor influencing output. However, Sollow (1956) argues that the advante of technology could increase outputs. Hence, Sollow built model called as Sollow Growth Model, which explain that the outputs of a country can ditermined by capital stock growth, labor, and the advances of technology. However, on the other hand an increase in output is not only determined by capital, labor, and technology advance but also determined by the growth of productivity. According to Mankiw (2006), productivity can be defined as the number of total goods and services produced by workers in each their working hours. How much total productivity produced by workers also be determined by capital. Capital can be devided into to parts; physical capital and human capital. Building, machine, land, and equipment or all factors used to produce which are physically exsisting be called as physical capital, while human capital is the qualitative dimension of human resource.

Some previous researchers have been conducted research about human capital and productivity. However, their research result is still showing different. Hendarmin, et.all (2019) investigates the impact of the human capital on the economic productivity level in provinces of Kalimantan Island during the period of 2013 to 2017 using panel data analysis. The result shows that human capital, measured by the education level which is the average of years of education, the health level which is life expectancy and investment has a positive effect on the productivity level of the regional economy. Moreover, health variable has a bigger magnitude compared to the education and physical capital investment variables.

Oluwabunmi (2017) analyze the causality between human capital and productivity growth in Nigeria during the period of 1970 to 2010. According to the Engle-Granger causality test, the research result shows that in Nigeria, the productivity growth has been very low and unstable as it oscillated between $-1.5 \%$ and $0.6 \%$. In addition, the relationship between human capital and productivity growth show that productivity growth caused human capital development, while human capital development does not cause productivity growth. 
Mohd Nahar, et.all (2015) investigates the impact of human capital on labor productivity on 14 states in Malaysia during the period of 2009 to 2012. The result show that according to the fixed effect model, that human capital quality has positive significant effect in improving the level of labor productivity in Malaysia. Their estimate suggest that the impact of health on labor productivity is greater than the impact of education. Improvements in the quality of health and education are therefore crucial for Malaysia to achieve higher productivity growth.

Farah and Puspita (2014) conducted research to analyze the influence of human capital quality to productivity level in Indonesia in the period of 1996-2006. Level education and health rate are used to measure human capital quality. Their research result shows that level of education has positive significant influence to productivity while health rate has negative significant influence. Beside, their result also show that level of education has stronger influence to productivity than health rate.

The research of the influence of level of education and health rate to productivity level also be conducted by Ameliyah (2013). Her study analyzing about human capital and productivity in Tangerang regency in the period of 2002 to 2010 using time series data analysis. Her reseach result shows that level of education has no significant effect on labor productivity, wheras health rate has positive significant to labor productivity. Sihombing (2009) analyzing the influence of human capital to productivity through level of education and health rate in Dairi regency, North Sumatra Province during 1993 to 2003 . His research result shows that level of education is not significant, but health rate has positive correlation to productivity. Partially, both variables have positive significant correlation to the level of labor productivity.

Some economy figures build definitions about human capital. Accrording to Agenor (2004), skills, knowledge of individual worker and consisting of abilities can be used to view human capital. Schultz (1961) consider that human capital is qualitative dimension of human resource which similar with skill and expertise that influence the productivity of a person. Backer (1994) argues that investment in health and education will have something of return in the future. Therefore, an increase in education and health investment will lead to an increase people productivity in the future.

De la Fuente (2011) built hypothesis about human capital which is human's knowledge and skill will directly increase both productivity and economic capability in order to develop and adopt new technologies. According to this hypothesis, on 1992 Mankiw et al developed human capital model by modifying Solow Growth Model by adding human capital accumulation in to production function known as Mankiw Romer and Weil (MRW). MRW model formulates production as:

$Y(t)=K(t) \alpha H(t) \gamma(A(t) L(t)) 1-\alpha-\gamma$

Where; $\mathrm{K}$ is physical capital, $\mathrm{H}$ is stock of human capital, A is technology and $\mathrm{L}$ is labor.

Equation (1) can be written in the form of per effective labor as:

$y(t)=\pi(t) \alpha \hbar(t) \gamma$

Physical capital and human capital are the part of capital. Therefore, the formula of capital acummulation can be written as

$$
\begin{aligned}
& \dot{\vec{k}}(t)=s_{k} \tilde{y}(t)-\left(\delta+n_{L}+n_{A}\right) \tilde{k}(t) \\
& \dot{h}(t)=s_{h} \tilde{y}(t)-\left(\delta+n_{L}+n_{A}\right) \vec{h}(t)
\end{aligned}
$$

Where; Sk and Sh is saving rate of physical capital and human capital, $\delta$ is depreciation rate, $\mathrm{nL}$ is population growth rate, and $\mathrm{nA}$ is technological growth rate. Steady state is a condition when capital accumulation does not occur, or when $\dot{\vec{k}}=0$ and $\hat{\hbar}=0$. Physical capital in steady state condition can be written as:

$$
\begin{gathered}
\dot{\hat{h}}(t)^{*}=\left(\frac{S_{H}{ }^{1-\alpha} S_{K}{ }^{\alpha}}{\delta+n}\right)^{1 / 2-\alpha-\gamma} \\
\dot{\vec{k}}(t)^{*}=\left(\frac{S_{K}{ }^{1-\alpha} S_{H}{ }^{\alpha}}{\delta+n}\right)^{1 / 2-\alpha-\gamma} .
\end{gathered}
$$


Using equation (5) and (6) into equation (2), the output per capita in steady state condition can be written as:

$\dot{\tilde{y}}_{(t)^{*}}=\left(\frac{S_{K}{ }^{\alpha} S_{H}{ }^{\gamma}}{\delta+n}\right)^{1 / 1-\alpha-\gamma}$

Equation (7) explains that physical capital accumulation rate and human capital can influence steady state of output per effective worker. This equation explicitly shows that output per effective worker is determined by physical capital and human capital investment.

Human capital is one of vital roles in the process of growth and economic development. The achievement of economic growth is depending on the improvement of physical capital and natural capital. Besides those two capitals, human capital also become the important key in order to increase productivity.

Further, Becker (1993) explain that humans are not only a resource but also an investment. This is due to human investment have generate return through their value added. The value added of human made when their skill and education is used by company. Therefore, education and training can be used to measure human capital.

Generally, according to Hendarmin (2019), the investment can be defined as the spending to purchase the good of capital and production pieces of equipment to advance the ability to produce goods and services in the economy. An increase in adding of the capital goods amount leads to an increase in it possibility to produce more goods and services in the future.

\section{RESEARCH METHODS}

Panel data analysis is used as research method. This is because panel data analysis has greater data variation and has smaller collinierity in each variable rather than time series data and cross section data (Gujarati and Potter, 2009). In addition, Batalgi (1998) explains that panel data has ability to control indiviual heterocedasticity that leads to bias estimation. Therefore, the estimation of panel data analysis does not need to conduct classical assumption test.
In the Panel data analysis there are two model, namely Fixed Effect Model and Random Effect Model. Fixed Effect Model assums that each individual differences can be accommodated from it's intercept distinction. Furthermore, Random Effect Model assums that the diffrences of individual intercept is random or stochastic.

This research uses secondary data collected from the publication East Java Provoice's Central Bureu of Statistic focusing on 29 regencies and 9 municipalities in East Java Province during the period of 2009 to 2015 . The research model is developed refres to the econometrics model developed by Ameliah (2013), where human capital is used as independent variable and productivity as dependent variable. Productivity is measured by GDP per labor whereas education and health are used to measured human capital. The literacy rate is used to measure level of education and infant mortality rate is used to measure health rate. Data on productivity, literacy rate and infant mortality rate are on percentage. Therefore, we can develop the econometrics model as:

$L P R O D_{i t}=\alpha_{i}+\beta_{1} E D U C_{i t}+\beta_{2} H E A L T H_{i t}+\mu_{i t} \ldots . .(9)$

Where; LPROD is logarithm of productivity per worker, $\beta 0$ is intercept, $\beta 1$ and $\beta 2$ are coefficient, EDUC is level of education, HEALTH is health rate, $i$ is index unit and $t$ is time index.

In this research, we develop two research hypotheses as the following level of education, measured by literacy rate, has positive significant correlation to productivity, health rate, measured by infant mortality rate, has negative significant correlation to productivity.

\section{RESULTS AND DISCUSSION}

Before analyzing the regression result, descriptive statistics of the maximum value, minimum value, mean, and standard deviations are presented in Table 1.

According to Table 1, variable productivity has a maximum value of $-5.82 \%$, minimum value of $-4.25 \%$, mean of $-3.12 \%$, and 
the standard deviation is 0.70 . Then, variable level of education has maximum value of $98.86 \%$, minimum value of $64.81 \%$, mean of $90.38 \%$ and the standard deviation is 6.66 . Finally, variable health rate has a maximum value of $67.89 \%$, minimum value of $16.89 \%$, mean of $32.20 \%$ and the standard deviation is 12.32 .

Table 1. The Maximum Value, Minimum Value, Mean and Stanard eviation

\begin{tabular}{lrrr}
\hline & Productivity & $\begin{array}{l}\text { Level of } \\
\text { Eucation }\end{array}$ & $\begin{array}{l}\text { Health } \\
\text { Rate }\end{array}$ \\
\hline $\begin{array}{l}\text { Maximum } \\
\text { Value }\end{array}$ & $-5.82 \%$ & $98.86 \%$ & $67.89 \%$ \\
Minimum & $-4.25 \%$ & $64.81 \%$ & $16.05 \%$ \\
Value & & & \\
Mean & $-3.12 \%$ & $90.38 \%$ & $32.20 \%$ \\
Standard & 0.70 & 6.66 & 12.32 \\
Deviation & & & \\
\hline
\end{tabular}

In panel data analysis, there are three analysis models: Common Effect Model, Fixed Effect Model, and Random Effect Model. Chow test is an analysis tool to examine the best model between Common Effect Model and Fixed Effect Model, and Hausman test is an analysis tool to examine the best model between Fixed Effect Model and Random Effect Model. This research does not conduct Chow test because Common Effect Model has some weaknesses, including its inability to observe several individual and time dimensions. Therefore, this research focuses on Hausman test to have the best result between Fixed Effect Model and Random Effect Model. Hausman test can be performed by comparing the P-Value (Prob) and critical value. The Hausman test hypothesis can be written as: H0: Random Effect Model

H1: Fixed Effect Model

From those hypotheses, H0 is not rejected if the chi-square statistic < chi-square table or $\mathrm{P}$ value (Prob) $>\alpha(5 \%)$.

According to the Hausman test result, this research finds that the number of Cross-section Random < alpha (0.05). It means that this research should reject $\mathrm{HO}$ or, other words, the best result is Fixed Effect Model. Table 2 shows bellow the coefficient of Fixed Effect Model, probability, and critical value.

Table 2. The Coefficient of Fixe Effect Model, Probability and $\alpha$

\begin{tabular}{lccc}
\hline Variables & $\begin{array}{c}\text { Coefficient } \\
\text { of Fixed } \\
\text { Effect }\end{array}$ & $\begin{array}{c}\text { P - } \\
\text { Value }\end{array}$ & $\alpha$ \\
\hline $\mathrm{C}$ & -2.591195 & 0.0000 & $5 \%$ \\
Level of & 0.003215 & 0.6343 & $5 \%$ \\
Education & & & \\
Health Rate & -0.081484 & 0.0000 & $5 \%$ \\
\hline
\end{tabular}

According to Fixed Effect Model, variable of level of education as measured by literacy rate has P-value (Prob) equals to 0.6343. This number is greater than $\alpha(5 \%)$. It means that variable level of education is not significant to influence productivity. The reason for that is because most workers in East Java Province are only graduated from elementary school and work in agricultural sector, which is not really need educated workers. They prefer to have workers with skills and experiences. Therefore, education rate measured by literacy rate cannot be used as good reference to analyze the influence of level of education to productivity in East Java Province case and we need other proxies for education. This research result is not consistent to the theory, but it is similar to the research result of Ameliyah (2013) and Sihombing (2009).

Variable of health rate as measured by infant mortality rate has P-value (Prob) of 0.0000. This number is smaller than $\alpha(5 \%)$. Therefore, this research concludes that variable of health rate as measured by infant mortality rate is significant influencer of productivity. The coefficient value of health rate as measured by infant mortality rate is -0.081 . It means that if infant mortality rate decrease as $1 \%$, the productivity will increase as many as $0.081 \%$ in ceteris paribus assumption.

The decrease of infant mortality rate is indicating that the health rate is good. Health, therefore, is an important feature to increase productivity. Healthy workers would be more productive than unhealthy one. 
The government also has important role to increase the quality of workers by improving HDI since an increase in HDI would lead to an increase in the quality of human resources and eventually lead to an increase in productivity. This research result is similar to the research result of Farah and Puspita (2013).

\section{CONCLUSION}

According to the data analyze result, this research makes two conclusions. First, the level of education variable is not significant in influencing productivity in the case of East Java Province.

The reason for this finding is because most of inhabitants of East Java Province are only graduated from elementary school and they work in agricultural sector that is more concerned with possession of skills and experiences, instead of level of education. Second, health rate as measured by infant mortality has negative significant correlation to productivity. A decrease in infant mortality rate is indicating that the health rate is good which eventually leads to an increase in productivity. Hence, a good health rate of labor will increase productivity and it is important for the government to invest more in this issue.

\section{REFERENCES}

Afrooz, Ahmad (2010), "Human Capital and Labor Productivity in Food Industries of Iran," International Journal of Economics and Finance, 2 (4), 47-51.

Agenor, Richard Pierre (2004), "The Economics of Growth and Adjustment". Havard University. UK. 2nd Edition.

Ameliyah, Poppy (2013), "The influence of Level of Education and Health Rate to Productivity of Labor in Tangerang Regency in Periods 20022011". Unpublished manuscript. Universitas Negeri Islam Syarif Hidayatullah: Jakarta.

Alma, M-S, and Kristina, M (2018), "Impact of Human Capital Development on Productivity Growth in EU Member States," Business, Management and Education, 16(1), 1-12.

Alnachef, T.H, and Anas, A.A (2015), "Effect of Human Capital on Organizational Performance: A Literature Review,"
International Journal of Science and Research (IJSR), 6 (8), 1154-1158.

Arshad, M.N. and Zubaidah Ab Malika (2015), "Quality Of Human Capital and Labor Productivity: A Case Of Malaysia," International Journal of Economics, Management and Accounting 23 (1), 37-55.

Becker, Gary,S (1994), "Investment in Human Capital: Effects on Earnings". National Bureau of Economic Research, Inc .NBER Chapters,in: Human Capital: $A$ Theoretical and Empirical Analysis with Special Reference to Education, 3, 29-58.

De la Fuente, A., \& Domenech, R. (2006). "Human Capital in Growth Regressions: How Much Difference Does Data Quality Make" Journalof the European Economic Association, 4 (1), 1 - 36.

De la Fuente, A. 2011. Human Capital and Productivity. Barcelona Graduate School of Economics.

Farah, Alfa, and Puspita Sari, Erlinda (2011), "Human Capital and Productivity". Journal of Economics and Policy. Universitas Diponegoro, 07 (1), 2228.

Mankiw N. G., R., D., Weil, D.N (1992), “A Contribution to the Empirics of Economic Growth". Quarterly Journal of Economics, (107), 407-437.

Hendarmin and Metasari Kartika (2019), "The Relationship Between Human Capital and the Regional Economy Productivity," Jejak 12 (1), 138-152.

Mankiw, Gregory N (2006), "Principles of Economics". Thomson South-Western. USA. 3rd Edition.

Schultz, T. W. (1961), "Investment in Human Capital". The American Economic Review, 51 (1), $1-17$.

Sihombing, A. Buyung (2002), "Population Studies in Development". Medan: Economics Journal PPS Unimed.

Solow, R. M (1956), "A Contribution to The Theory of Economic Growth". Quarterly Journal of Economics, 70 (1), 65-94.

Sumual, Tinneke, Arif F.K, Johny, M (2017), "Increasing Employee Productivity through Human Capital and Organizational Capital," International Journal of Business and Management Invention, 6 (9), 16-21. 